\title{
Second Thoughts About Central Bank Digital Currencies
}

\author{
Arto Kovanen ${ }^{1}$ \\ ${ }^{1}$ Kovanen Macroeconomic Policy Advising, L.L.C. \\ Correspondence: Arto Kovanen, Principal, Kovanen Macroeconomic Policy Advising, Alexandria, VA, USA.
}

Received: November 2, 2021

Accepted: November 25, $2021 \quad$ Available online: December 29, 2021

doi:10.11114/aef.v9i1.5434

URL: https://doi.org/10.11114/aef.v9i1.5434

\begin{abstract}
Sustained decline in central banks' monetary liabilities (reserves and currency in circulation), which the emergency of cryptocurrencies may have hastened, has been enabled by technological innovations that over time have allowed financial institutions and their customers to execute transactions and settle their debts without resorting to central bank currency. Policymakers are concerned about their ability to guarantee public's access to government-backed currency. This has implications for central banks' balance sheet and income position, which central bank digital currency might reconstitute. But the introduction of central bank digital currency (CBDC) comes with its own risks and could be disruptive for financial markets. We believe that retaining the option to have access to government-guaranteed currency is of utmost importance, despite the sporadic demand for physical currency in the modern society, but it could be addressed within existing institutional structures without the introduction of CBDC. However, policy authorities are right in seeking oversight and regulation for cryptocurrencies to address the destabilizing potential of cryptocurrencies for financial markets, and they should continue modernizing payment infrastructures to bring retail settlement systems at par with cryptocurrencies in terms of settlement speed but without associated liquidity and credit risks. These steps would preserve the status quo and allow private sector to continue innovating while limiting central banks' footprint in the financial markets.
\end{abstract}

Keywords: central bank digital currency, legal tender, monetary policy effectiveness, nominal anchor, payment and settlement, financial market stability, stablecoin

JEL Classifications: E4 and E5

"The question in the first instance is whether technological innovations will impair the central bank's ability to carry out operations that reliably affect economic activity in the usual sense of real output and/or price inflation". (Friedman, 2000)

"The most dangerous weapon in the galaxy is money, Captain".

(A quotation from Star Wars movie)

\section{Introduction}

Throughout history, there have been innovations that have led to unexpected, and often times profound, changes that have shaped financial markets and the way people access financial services (Note 1). Sometimes changes come quickly, as evidenced by the propagation of cryptocurrencies (Note 2). It was not that long ago when people had to visit a branch office of a local bank to make a deposit, pay a bill, or withdraw money. Even debit and credit cards and automated teller machines (ATMs) are relatively new phenomena, although nowadays they seem ancient (Note 3). Many forms of financial transactions may be carried out from the convenience of your own home, another innovation, by accessing online banking services through a computer or a mobile phone, thanks to technological possibilities and connectivity (high-speed Internet). Because of these types of advances, it is hardly surprising that demand for physical currency has dwindled, in the United States and everywhere else, as making payments with physical cash have been overtaken by electronic alternatives (e.g., Federal Reserve System, 2019). It is possible that the Covid-19 pandemic and cryptocurrencies have hastened the transition away from physical currency, as the public would prefer contactless options (e.g., applications in smart phones). But they have not altered the longer-term trajectory. This has raised concerns among policymakers about the future of government-backed currency, its role as a payment instrument, and how to ensure public's access to it for those who still want to use it (many of us don't, but some segments of population 
rely on having physical cash at hand). Worries have been expressed also about the implications of electronic payment alternatives for monetary policy effectiveness and financial stability, which has prompted the interest in central bank digital currencies (CBDCs).

However, the transition away from physical currency is just another development in the longer-term trend that has contributed to the declining demand for central bank monetary liabilities (i.e., currency in circulation and reserves), which has taken advantage of technological innovations that have enables financial institutions and retail customers to conduct financial transactions without the need to resort to central bank money. A similar development in the financial markets took place some twenty years ago, evidenced by the steady fall in the demand for central bank settlement liquidity. It caught the attention of economists and policymakers and led to concerns about its consequences for monetary policy and price stability (Figure 1, orange line) (Note 4). Continued decline in the demand for the U.S. dollars in circulation follows a similar downward trend, as is illustrated by the solid and dotted blue lines in Figure 1. This reflects the above-mentioned shift towards electronic, non-cash payments, which have become widely accepted, reliable and secure. Because of its status as a global reserve currency, the demand for U.S. dollars has nonetheless remained robust, particularly outside the United States (Figure 1, solid blue line). Haasi, Schulhofer-Wohl and Paulson (2018) estimate that a significant and increasing share of U.S. dollars circulate outside the United States (Note 5). We adjust the demand for U.S. dollars in the United States to the share of dollars held abroad and conclude that it might have fallen to 3 percent of GDP in 2020 (Figure 1, dotted blue line). It is worth pointing out that the use of physical currency as a means of payments in the United States is already small compared to the total value of noncash payments (cash payment represented 0.7 percent of noncash payments in 2018, the latest figure available).

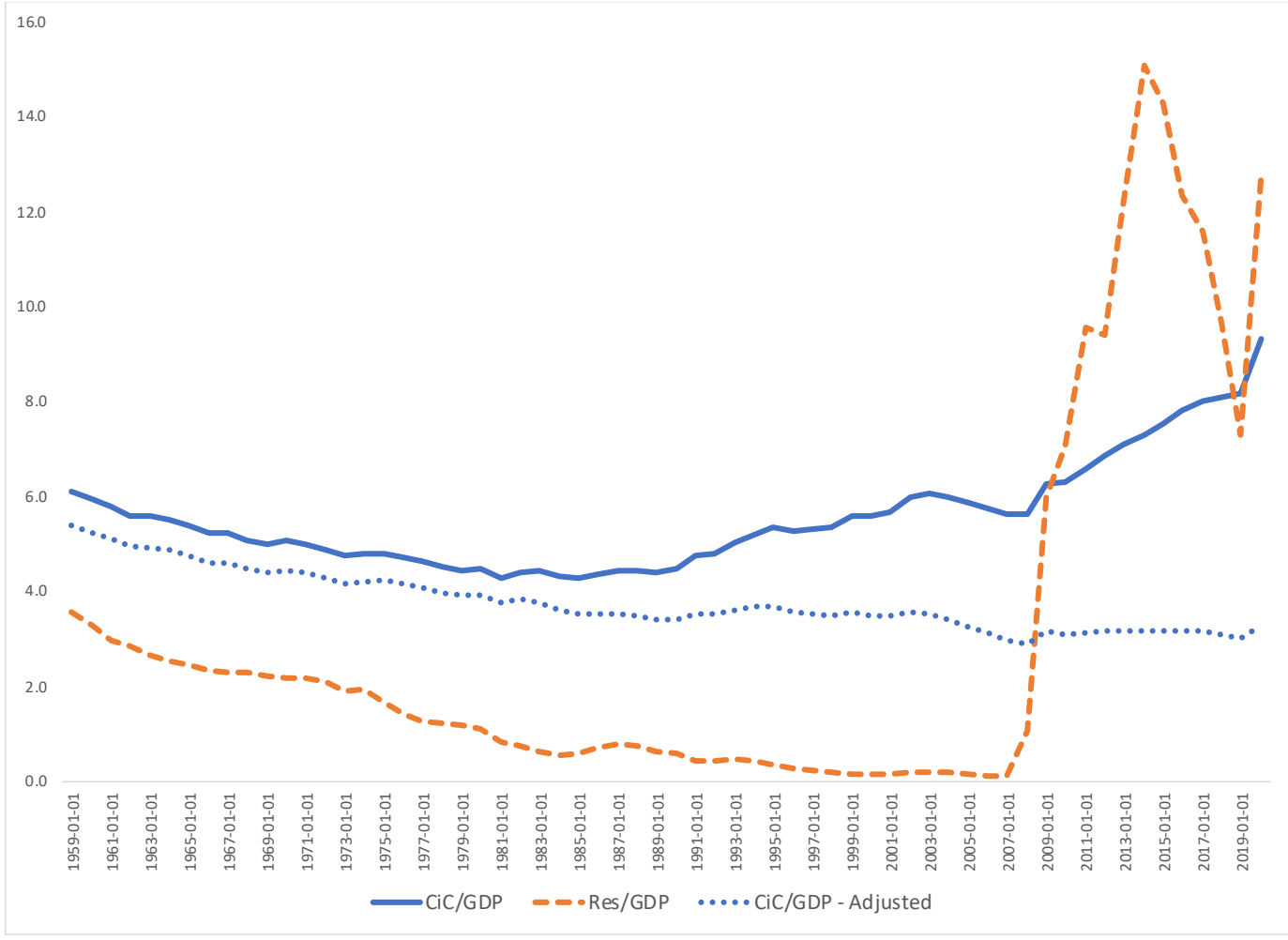

Figure 1. Currency in Circulation and Bank Reserves (1959 - 2020, in percent of GDP at annual rate)

Sources: Federal Reserve Bank of St. Louis (FRED) and author's calculations

The above numbers suggest that in many ways we have already reached a state where demand for government-backed currency has effectively disappeared (abstracting from intermittent use) or has become marginal relative to other forms of payments. Negative network externalities and the profitability (or the lack of it) of providing teller services and maintaining AMT networks have probably accelerated the decline in the provision of physical currency services to the public (Note 6). However, private payment alternatives have their own challenges, as they may be imperfectly substitutable, which underscores the interest in preserving government-backed currency as a unique nominal anchor. Without a clear mechanism to establish a nominal anchor to help transform a payment instrument into another in the cashless economy, relative prices of different bank deposits and digital network currencies could become unhinged from 
the one-to-one parity that is currently enjoyed between inside and outside money (which makes a dollar always worth one dollar, i.e., there is no exchange rate risk). Then issuer's credit worthiness and liquidity of the instrument become key to the valuation of financial instruments.

Aside from the implications for central bank monetary liabilities, it is well understood that cryptocurrencies represent potential risks to settlements because transactions are handled by way of unregulated, peer-to-peer networks. This has led to concerns among policymakers, and rightfully so, about the legal status and finality of the settlements and their ability to ensure that the public has access to a safe and efficient payment system. In most countries, payments systems are operated by both the central bank and private sector, as countries use multiple payment platforms, each of them catering to a specific market segment (for instance, wholesale or retail settlements, and payment systems feature real-time and deferred settlement modes). Nevertheless, central bank remains pivotal for ensuring the safety and efficiency of these arrangements. As digital innovations reshape payment services (e.g., Bank for International Settlements (BIS), 2020), policy authorities find themselves confronted by new demands for ensuring the safety and integrity of digital payment platforms.

The proliferation of cryptocurrencies should be viewed as the latest phase in the evolution of financial markets and instruments. Despite their rapid rise, which is taking the full advantage of the cutting-edge technological possibilities, they are unlikely to compromise monetary policy and its effectiveness and the maintenance of price stability (although the developments could be unsettling in the short run). Although they are still in their infancy, cryptocurrencies have already distinguished themselves by their unique features, in particular their ability to verify and process transactions using peer-to-peer networks, which are outside regulated systems. This is a remarkable achievement and illustrates how far we have come in a rather short period of time. The following quotation by Freedman (2000) exemplifies this as he expresses his sentiments two decades ago about the evolution of financial services: "Perhaps I am being short-sighted, but I find it hard to envision (except in the most abstract way) a world in which 6 billion people have accounts on a central computer and funds are transferred among them as they sell assets to make payments" (Note 7). In all respect, we are already living in that kind of world (Note 8)!

Historically, governments have sought to regulate private money creation to safeguard financial systems because an unfettered money issuance has often ended poorly (e.g., during the free banking era in the United States). If digital currencies succeed in fully exploiting the value of the associated networks, the financial system could become centered around digital platforms where the public writes contracts in a unit of account specific to a platform (e.g., Tether and USD Coin) rather than in central bank's unit of account (e.g., the U.S. dollar) (Note 9). This could alter the financial hierarchy in a profound manner. Furthermore, the relevance of traditional banking could diminish, or even disappear, as network providers invade the space traditionally occupied by banks, unless traditional banks begin to offer similar services (which is likely). If the financial system becomes centered around a network of privately issued digital currencies, some entity (most likely a central bank) may need to provide emergency liquidity (backstop facility) to the issuers of private digital currencies at times of financial stress, similar to current lender-of-last-resort arrangement available to banks, to avoid financial collapse. This is not possible under current regulations.

The proliferation of private cryptocurrencies has led to concerns among policymakers about the future of government-backed currency and potential for instability in the financial markets, as transactions are increasingly processed by private and often times globally owned conglomerates (e.g., Visa and PayPal) while the demand for government-backed currency (banknotes and central bank reserves) continues to decline. There is a broad interest among central bankers to study the implications of these developments and whether central banks should introduce their own digital alternatives to physical legal tenders (CBDCs). Riksbank, the monetary authority of Sweden, is among several central banks on the forefront of this analysis. Given fading demand for physical currency, which in Sweden represented only 1.25 percent of GDP in 2020 (lower than in the United States), Riksbank has expressed worries about the possibility that the continuation of the current trend could lead to a situation where the public is left dependent on private sector payment solutions. The authorities indicate that this could make it difficult to guarantee the safety and efficiency of national payment systems and at times of financial market stress (e.g., during the Covid-19 pandemic) public's access to government-backed currency (Sveriges Riksbank, 2018 and 2020). Other central banks have expressed similar sentiments.

The introduction of CBDC is thought by many as a countermeasure that would guarantee an uninterrupted access to government-backed currency and address other policymakers' concerns about cryptocurrencies. This highlights how important it is for policymakers to safeguard the credibility of the nominal anchor (which, historically, private sector has had difficulties to establish) and the convertibility of private (inside) money into government-backed (outside) money. This guarantee, even if not exercised frequently, that the public has access to government-backed money and is able to convert it at one-to-one rate on demand, eliminates the failure arising from informational asymmetry among imperfectly substitutable private currencies. The CBDC enables central bank to enforce its unit of account (nominal anchor), which 
is critical for maintaining central bank's monetary authority and the credibility of the financial system.

Available literature offers a range of suggestions for CBDC. An early analysis of Berentsen (1997) on digital money, even before the introduction of Bitcoin, highlights key issues for policymakers and, among other things, emphasizes the importance of interoperability of e-money for reaching a wide acceptance (Note 10). Bjerg (2017) provides a taxonomy of private and public money and shows that CBDC could coexist with currency and commercial bank deposits. Bordo and Levin (2017), among many others, endorse a full-fledged, account-based approach to CBDC that is interest-bearing, to facilitate nearly costless exchanges and provide a safe storage of value and stable unit of account. Barrdear and Kumhof (2016) and Auer and Böhme (2021) criticize private sector solutions as inefficient (e.g., costly decentralized verification of transactions) and endorse CBDC as an alternative (BIS, 2018a). Chiu, Davoodalhosseini and Zhu (2019) suggest that $\mathrm{CBDC}$ could also promote efficient intermediation by compelling monopoly banks to raise interest rates on bank deposits. Keister and Sanches (2019) endorse an interest-bearing CBDC to enhance public welfare and reduce intermediation costs even if this crowds out credit-constrained private lenders. Piazzesi and Schneider (2020), however, argue that CBDC could reduce public welfare if the central bank only offers CBDC but not credits. Andolfatto (2018) and Engert and Fung (2017) suggest that CBDC could promote financial inclusion. Meaning, Dyson, Barker and Clayton (2018) conclude that monetary policy with CBDC would operate much the same way as currently but CBDC would strengthen monetary policy transmission. Gupta, Lauppe and Ravishankar (2017) discuss possible feature of Federal Reserve's digital currency (called the Fedcoin). See also Ammous (2016), Bech and Garratt (2017), Davoodalhosseini and Rivadeneyra (2018), and Fernándes-Villaverde and Sanches (2018).

However, some authors have reservations about CBDC. Bindseil (2020) endorses a more limited role for CBDC and proposes a tiered interest rate structure to address potential problems with the full-fledged CBDC. Auer and Böhme (2021) propose a "minimally invasive" approach to CBDC. Kumhof and Noone (2018) would limit access to CBDC and keep it separate from cash and bank reserves, among other things (e.g., adjustable interest rate, unguaranteed convertibility from bank deposits, full backing and prohibition to exchange it for bank reserves). Berentsen and Schär (2018) caution against anonymity of the user and access without a permission, as that could give rise to potential reputational risk. Carstens (2021) doubts that purely anonymous CBDC would work and consequently some forms of identification and account-based access would be likely. He argues that public trust is pivotal for digital services. Kovanen (2019a) expresses reservations about the full-fledged CBDC, highlighting similar concerns and potential for conflict of interest (central banks would be competing with institutions they supervise). Adrian and Mancini-Griffoli (2019) propose a synthetic CBDC as an alternative to full-fledged CBDC, which would preserve the comparative advantage of the private sector to innovate and interact with the public. Waller (2021) expresses skepticism about the desirability of issuing dollar denominated CBDC in the United States. Cecchetti and Schoenholtz (2021) suggest that CBDC is not necessary and speculate that central banks might be pursuing it out of the fear of "missing out". See also Adrian and Weeks-Brown (2021).

No major central bank has so far introduced its own CBDC that would complement physical currency, although there are plans for doing so (e.g., China and Sweden, among others, are moving to that direction). This reflects numerous questions and uncertainties that need to be resolved as the introduction of a retail digital currency by a central bank could have far-reaching implications (Note 11). It is possible that CBDC could destabilize the financial system, which the authorities clearly wish to avoid. While it would provide the public a new channel to access government-backed currency at a much broader scale than currently possible, it might lead to financial disintermediation (the public might prefer CBDC to bank deposits). It would also expand central bank's footprint in the financial market, possibly beyond what would be appropriate (e.g., creating a central bank centric banking system where the central bank acts as the first rather than the last resort). Furthermore, because CBDC could be designed as interest-bearing, it could provide central bank with a new monetary policy instrument to steer market interest rates, which could dilute the role secondary markets in pricing credits and liquidity. These highlight the need to proceed cautiously with the introduction of CBDC.

This article contributes to the rapidly expanding literature on CBDC and its implications for central banks (Note 12). We discuss the proliferation of cryptocurrencies in the context of the longer-term evolution of financial markets where cryptocurrencies are seen as the latest development in the process that features a steady decline in the demand for government-backed currency and reserves. In this paper, we highlight its implications for central bank's balance sheet and income position, which could be one motivation behind central banks' interest in CBDC but would not necessitate represent the best solution. The rest of the paper is organized as follows. Section 2 revisits two-decades old discussion about falling reserves and their implications for monetary policy effectiveness and price stability. This is relevant for the current discussion about cryptocurrencies as similar concerns about policy effectiveness have been raised in the context of cryptocurrencies and their possible implications for central bank money. We argue that policy effectiveness would not be compromised by falling demand for central bank monetary liabilities (currency and reserves), but the decline has other consequences, including for central bank's income, which could compromise its policy independence and effectiveness indirectly and lead to a situation where central bank becomes dependent on government financing. In our view, this issue has not received enough attention (although it was discussed at some length two decades ago). This is discussed in Section 
3. In Section 4, we propose a solution to protect access to government-back currency, which encompasses a minimum cash requirement. We argue that it offers a simple and more cost-effective alternative to CBCD. In Section 5 we endorse policy measures to strengthen the oversight of cryptocurrencies and to provide a "level playing field" in settling private claims. In Section 6, we examine "money-like" properties of cryptocurrencies and emphasize similarities between cryptocurrencies and foreign currencies in Section 7. Section 8 offers some final thoughts.

\section{Demand for Government-Backed Money}

The steady decline in the demand for government-backed currency, in the United States and around the world, has been happening for some time, which should be seen as part of the evolution of the financial markets. Technological innovations and more recently the Covid-19 pandemic, have accelerated the transition away from central bank currency as the public increasing prefer electronic and contactless alternatives to physical currency. Negative network externalities, as already mentioned, are making it more costly for banks and other financial institution to maintain the necessary infrastructure for teller and cash services. Furthermore, policymakers have raised concerns about access to government-backed currency, when needed, particularly during times of financial stress when the demand for currency usually rises (Note 13). Protecting access to government-backed is of paramount interest but can be achieved without the introduction of CBDC. Concern about the future of government-backed currency is closely related to the future of the more general decline in the demand for central bank's monetary liabilities (encompassing currency and reserves) and its implications for monetary policy and price stability.

\subsection{Is It a Déjà $V u$ ?}

Some twenty years ago central bankers and economists became concerned about central banks' capacity to conduct monetary policy in the world of declining reserve levels (Figures 1 and 2) and whether policy authorities would be able to steer market interest rates and liquidity conditions effectively to achieve their policy mandates (such as full employment and price stability). Secondary market developments had enabled financial institutions to manage their liquidity without resorting to central bank reserves. Clearinghouse money and so-called Treasury money became the primary means for settlements and banks held balances at the central bank for precautionary purposes (in excess of the statutory levels). Figure 2 shows that depository institutions' reserves fell from around 40 percent of monetary base in the 1950s to less than 2 percent in August 2008, at which point monetary liabilities comprised mainly Federal Reserve's notes (currency in circulation) (Note 14). The Global Financial Crisis in 2008 interrupted the trajectory in reserve holdings and nowadays banks' reserve balances account for about one-half of the Federal Reserve's monetary liabilities.

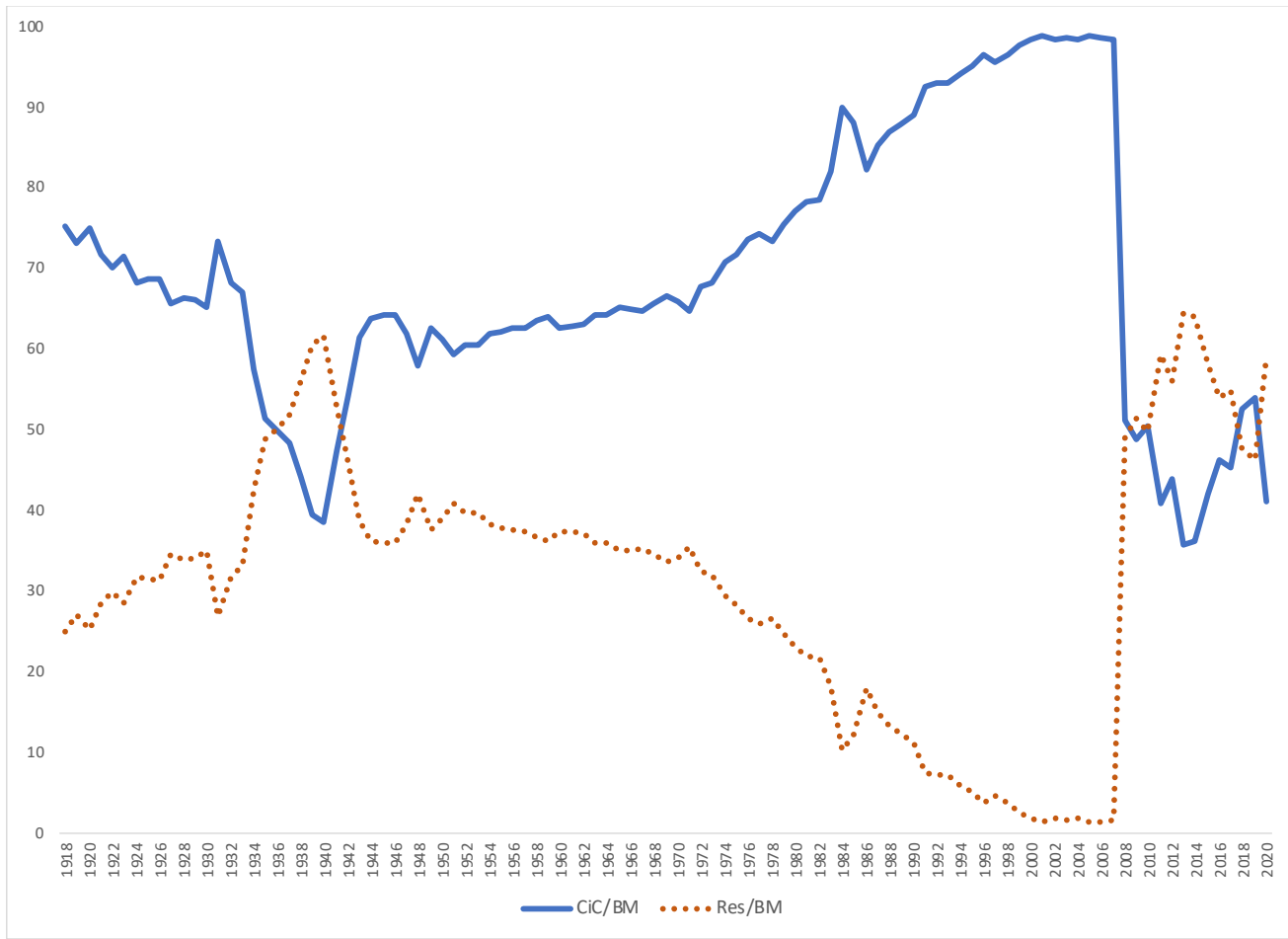

Figure 2. Currency in circulation and bank reserves (1918 - 2020)

(In percent of monetary liabilities of the Federal Reserve System)

Sources: Federal Reserve System (2020) and author's calculations 
Did fading demand for reserves undermine monetary policy effectiveness and increase risks for settling claims? A simple answer is it did not. Several papers examined this issue at the time, including Woodford (2000) and Henckel, Ize and Kovanen (1999). These research papers conclude that policymakers' concerns were largely misplaced because the monetary authorities could continue to implement monetary policy effectively and target short-term interest rates. Even in the absence of monetary liabilities central banks can continue to influence the cost of borrowing in the secondary markets. In this context, Friedman (2000) was concerned about the "decoupling" risk, a situation where financial claims would be created and transacted in the financial markets in ways that would affect spending and investment decisions of the households and firms while the policy rate set by the central bank would become disconnected from interest rates and asset prices that matter for the economy (Note 15). It is reasonable to conclude in hindsight that policy effectiveness was not at risk due to the declining reserve levels.

\subsection{Monetary Policy in a Cashless Economy}

Are policy implications different for disappearing government-backed currency? That is, would cashless economy undermine monetary policy effectiveness? Again, the answer is probably no. For instance, Woodford (1997) examine the effectiveness of monetary policy in a cashless economy where the fraction of transactions subject to the "cash-in-advance" constraint approaches zero (at which point the economy becomes effectively "cashless"). Transactions in the United States are already virtually cashless, utilizing alternative electronic payment instruments. Woodford (1997) shows that the price level at the "cashless limit" continues to be defined and the effective control of short-term interest rates is still possible even in the complete absence of monetary frictions (i.e., paper currency). Henckel et al. (1999) conclude along similar lines that the capacity of the central bank to reach its policy target (i.e., short-term interest rate) and its final target (i.e., inflation) is not at risk due to falling demand for central bank money. They note that central bank could control the overnight interest rate (e.g., the fed funds rate) by using deposit interest rate as the floor for short-term market interest rates (Note 16).

As policymakers continue to search their "souls" for answers to challenges posed by private cryptocurrencies, there is a more fundamental question in the shadow. What makes central banks unique and distinguishes them from other financial institutions (Henckel et al. (1999))? We believe that answer to this question would undoubtedly help central banks to find solutions to the challenges posed by cryptocurrencies. Central banks are uniquely positioned to establish a nominal anchor for economy, which private sector is unable to accomplish (without such an anchor, for instance, nominal interest rates would be indeterminate) (Note 17). This requires that central banks continue to be able to steer short-term market interest rates. Have technological innovations impaired central banks' ability to carry out their operations that reliably affect economic activity in the usual sense of real output and/or price inflation (as pointed out by Freedman, 2000)? We believe that the answer is no. Other central bank functions, such as the supervision of financial institutions (which is already being handled by other entities that central banks in many countries) and the lender of last resort provision of liquidity, are not necessarily unique functions of the central bank and could be entrusted to other (government) institutions.

Woodford (2000) notes that if debts are contracted in the unit of the national currency in an economy where financial market participants are willing to accept as final settlement transfers that are made over electronic networks in which the central bank is not involved, clearing balances at the central bank would still define the metric against which these claims are accepted as equivalent (the nominal anchor). This is why the preservation of the one-to-one conversion rate between inside and outside money is so crucial for the market valuation of dollar deposits and central bank's monopoly position as a supplier of its monetary liabilities (even at the margin) would continue to define the unit of account in the economy through nominal yield on clearing balances, which determines the overnight interest rate in the financial market. This suggests that in a cashless economy (with no monetary liabilities) central bank would be able to enforce its own unit of account even in the absence of digital government-backed currency (CBDC), as long as it is able to influence market interest rates (at the margin) through its settlement account in the payment system. See King (1999).

\section{Central Bank's Balance Sheet}

The shrinking of monetary liabilities has other important consequences for central banks, which have not been discuss enough in the current context. Indirectly these could compromise policy effectiveness. Decline in monetary liabilities could impact negatively central banks' income position and profitability. Although the operations of central banks are not driven by profitability, but instead of policy mandates (such as full employment and price stability), unlike with commercial banks that are profit-focused entities, it is nonetheless crucial that central banks generate enough income to cover their operational expenses. Inadequate capacity could compromise central banks' operations and make them dependent on government financing, which could hamper their ability to achieve the above-stated policy objectives.

Presently, this is not a major concern for the Federal Reserve and for many other central banks, reflecting the expansion of their balance sheets in the aftermath of the Global Financial Crisis and the Covid-19 pandemic. Table 1 shows the Federal Reserve's balance sheet as of June 2021, which indicates that it holds almost $\$ 8$ trillion in Treasury and other 
federal agency securities and loans to financial institutions. These assets represent its main source of income. On the liabilities side, public's holdings of Federal Reserve's Notes (banknotes) are non-interest bearing and only carry the cost of printing. Financial institutions hold substantial reserve balances at the Federal Reserve (totaling almost $\$ 4$ trillion), as the result of large-scale liquidity operations. These balances, or part of them, earn interest (as per the Financial Services Regulatory Relief Act of 2008, which authorized the Federal Reserve to remunerate banks' reserve balances). Other liabilities include, among others, Treasury balances at the Federal Reserve (single Treasury account). The capital of the Federal Reserve is small relative compared to its balance sheet (about 0.5 percent), comprising paid-in capital $(\$ 32.8$. billion) and unallocated surpluses, leaving little room to absorb future operational losses (Note 18).

Table 1. Federal Reserve System: assets and liabilities (June 2021, in billions of dollars)

\begin{tabular}{lr|lr}
\hline \multicolumn{1}{l}{ Assets } & US\$ billions & Liabilities & US\$ billions \\
\hline & & & \\
Securities and other loans & $\$ 7,934$ & Base money (BM) & $\$ 6,027$ \\
Securitiies held outright & $\$ 7,505$ & Currency in circulation (CiC) & $\$ 2,179$ \\
Other loans & $\$ 428$ & Reserve balances (Res) & $\$ 3,848$ \\
Other assets & $\$ 145$ & Other liabilities & $\$ 2,012$ \\
& & Total capital & $\$ 40$ \\
& & & $\$ 8,079$ \\
\hline
\end{tabular}

Sources: Federal Reserve Bank of St. Louis (FRED) and author's calculations.

Suppose that all settlements are to take place on the books of private clearinghouses. In that situation, and if demand for currency were to all but disappear, traditional monetary liabilities (currency in circulation and reserve balances) would no longer be on the central bank's balance sheet. The key remaining liability would be the capital of the central bank (particularly, if all Treasury accounts were to be transferred to commercial banks). On the asset side of the balance sheet, there would still be claims on government in the form of Treasury and federal agency securities, but at a much smaller scale than before, mostly obtained from end-of-day repurchase operations. This would have significant (negative) implications for the Federal Reserve's income position and profitability, which we believe has not been emphasized enough in the context of cryptocurrencies and could be one motivation for the issuance of CBDC (as it would help reconstitute central bank's monetary liabilities).

The continuation of the current trajectory underscores the importance of ensuring that central banks remain profitable, or at least there is a mechanism in place that helps offset its operational losses, so that central banks could operate independently of political pressures. A longer-term decline in monetary liabilities therefore presents an important policy challenge for central banks. Research show that central banks' financial strength precedes their ability to conduct monetary policy effectively. Stella (1997), however, argues that central banks can operate without positive capital but recognized that negative net worth could risk their independence and ability to achieve their policy goals. In a subsequent paper, Stella (2008) concedes that financially weakness could make it difficult for central banks to maintain macroeconomic stability and could call into question central banks credibility. In the U.S. policymakers have not supported large capital for the Federal Reserve, which Stella (2008) interprets as evidence that capital has no implications for policy efficiency in the United States, because the Federal Reserve would always be able to create money to meet its financial obligations. That could have unintended macroeconomic consequences (such as inflation). Bindseil, Manzanares and Weller (2004) emphasize that positive capital is crucial to ensure that central banks remain unconstrained in their focus on price stability. They highlight risks to central banks' long-term profitability from slowing demand for banknotes (seigniorage) and point out that a credible mechanism to recapitalize central bank could offer a substitute for positive capital. Goncharov, Ioannidou and Schmalz (2018) argue that central banks are not indifferent about their profitability and have an incentive to avoid reporting losses as that could lead to political pressures and impact on central banks' independence (Note 19). See also Ize and Oulidi (2009) and Engert and Fung (2017) on this topic.

The consequences of declining demand for monetary liabilities could be addressed in two ways. First, central bank could artificially create demand for its monetary liabilities by requiring banks to hold settlement liquidity or reserves (i.e., central bank can impose statutory reserve requirement), which would be unremunerated and backed by interest-earning assets (Note 20). This could be implemented under current central bank statue and without the involvement of the legislative branch, which would preserve central bank's autonomy. Again, it would be a simpler and 
more cost-effective alternative to CBDC. Central bank could also ask its owner, the government, to increase its paid-in capital to generate income to support central bank's operations. This could be either one-off or automatic whenever the central bank depletes its existing capital due to operational losses (e.g., it might have issued its own securities (central bank bills) to absorb excess liquidity from the money market, whose interest would be paid for by the central bank, unlike in the case of using Treasury and agency securities in its operations whose interest cost would be absorbed by the issuer, i.e., government). However, recapitalization would require legislative approval (since the money has to be budgeted) and would subject the central bank to government's political influences, which it would probably want to avoid.

\section{Minimum Cash Requirement}

The ongoing transition towards online banking by depository institutions is challenging the provision of banking services more broadly for those individuals with limited access to modern technology. Policy authorities rightfully raise concerns that digitalization of the economy, evidenced by declining demand for physical currency and shift to electronic means for settlements, could hinder public's access to government-backed currency, however sporadic, for instance for individuals who do not have access to computers or smart phones, or do not know how to use them (e.g., Sveriges Riksbank, 2020). This underscores the reality that "there is no real substitute for hard cash". Public's access to government-backed currency has frequently mentioned as an important motivation for the issuance of CBDC. We wonder if the introduction of CBDC represent the best option in practice to overcome the above-mentioned obstacles for access to government-backed currency (i.e., people with no access to computers or smart phones, or the Internet).

Strengthening existing infrastructure that is critical for ensuring access to government-backed currency would offer the best solution, which motivates our proposal to require depository institutions to maintain adequate currency holdings and functioning ATM networks. This should be viewed as a public good because it benefits all of us and the government should be motivated to sponsor the cost of the provision of such services (Note 21). We recognize that not all countries impose statutory reserve requirements (or have set them to zero) on depository institutions, which reflects their unimportance for monetary policy purposes (money aggregates and money multiplier have become less important in inflation targeting frameworks). Reserve requirements still serve some purposes in a few countries (e.g., they might assist central bank's liquidity management and support settlements). O'Brien (2007, Table 1) provides a summary of the features of reserve requirement systems used by a group of central banks around the world (Note 22).

The minimum cash requirement should not be considered as a monetary policy or liquidity management tool. It is there to ensure access to physical currency by the public. We focus on two aspects important for the minimum cash requirement as a way to facilitate access to government-backed currency: designation of vault cash as the only eligible asset to meet the minimum cash reserve requirement and remuneration of minimum cash reserves. Most central banks do not allow vault cash to be counted as an eligible reserve asset, in part because of the difficulty to measure it in real time (i.e., without audits the central bank must rely on depository institutions' self-reporting). Only non-borrowed reserves held at the central bank are counted towards meeting statutory reserve requirements in countries who still require them. Important exceptions are Swiss National Bank and the Federal Reserve who permit vault cash as part of the statutory reserve requirement, up to 100 percent. On the other hand, the practice of remuneration (i.e., paying interest on balances at the central bank) is more mixed. Remuneration is usually applied only to required reserve balances, if at all, but not to additional (voluntary) reserves depository institutions may hold with the central bank. The interest rate is usually linked to the policy rate or another short-term interest rate (possibly with a discount). The Federal Reserve started paying interest on banks' reserve balances held with it after the Global Financial Crisis in 2008, which helps sponsor (at least indirectly, although the primary purpose of remuneration is to reinforce central bank's policy interest rate target) banks' cost of holding cash and maintaining ATM networks.

By introducing a minimum cash requirement for depository institutions, central bank should expect these institutions to maintain a minimum level of liquid assets in the form of banknotes and coins (e.g., how much depends on country-specific factors) (Note 23). This requirement would be separate from any other statutory requirements (such as liquid-asset and other reserve requirement ratios) and would need to be met with cash in the vault or held in ATM networks (Note 24). Furthermore, the currency requirement should be remunerated at some positive interest rate (e.g., the key policy rate if positive, or another short-term market rate) and up to the minimum statutory level. This would help offset the cost of maintaining cash balances and servicing distribution networks by banks. The minimum cash requirement could be averaged over the maintenance period if that is considered important for banks' liquidity management.

\section{Regulatory Oversight and Payment Infrastructure}

\subsection{Extend Regulatory Oversight to Private Cryptocurrencies}

When cryptocurrencies become highly scalable (e.g., Diem) and are being used across various blockchain platforms 
(network compatibility), they expand potential access to hundreds of millions of retail customers and could easily become substitutes to existing payments instruments. Arner, Auer and Frost (2020) suggest that the Diem could have systemic implications, provided that a large portion of money supply would be transferred from the banking system to cryptocurrency networks (see also Kovanen, 2019b). It is understandable that the Diem and other stablecoins raise regulatory and supervisory concerns, for financial market integrity, money laundering (AML/CFT), and consumer protection, among others. They could also challenge existing institutional frameworks and lead to financial instability. These sentiments are echoed by the Bank of England (BoE, 2021), which underscores that large-scale displacements of commercial bank liabilities by new forms of cryptocurrencies could mean that a higher percentage of money in the economy is backed by high-quality liquid assets (e.g., short-term government securities) rather than bank loans, which possibly could constrain credit supply. Sveriges Riksbank (2020) notes that global concentration of payment service providers represents a vulnerability for countries like Sweden.

This is an area where regulatory authorities in the United States and elsewhere have stepped up their scrutiny and are moving towards endorsing the need for regulation of cryptocurrencies, to ensure that new forms of digital money operate safely and do not destabilize the financial markets. We believe that this is the correct approach to address the potential adverse implication of private cryptocurrencies. One suggestion that has been offered is to establish a "level playing field" where stablecoins have to meet the same standard to those expected of commercial banks in relation to the stability of value, robustness of the legal claim and the ability to be exchanged at par value to central bank money if they are used in systemic payment chains as money-like instruments (e.g., BoE, 2021). It is likely that expected regulation of stablecoins would include capital and liquidity requirements similar to those banks are subjected to in order to protect the holders of stablecoins and the settlement systems. Stablecoins that offer no credits, less stringent regulatory requirements could be considered (e.g., as proposed by BoE (2021) and the International Monetary Fund (IMF, 2021)). That is, regulation should be designed in a manner that is proportional to risks these instruments present.

Reflecting the global reach of cryptocurrencies, international coordination is important. National regulatory authorities should agree on global standards and ensure close coordination of cryptocurrencies, to address their potential systemic financial stability risks (IMF, 2021). Furthermore, Fullenkamp and Nsouli (2004) point out that bringing stablecoins in the regulatory framework used for depository institutions could raise other considerations, such as the need to offer stablecoins the same benefits as to banks in return of regulation. Should stablecoins be allowed to access a backstop facility that would provide access to liquidity during financial stress (e.g., BoE, 2021)? Having a backup facility would reduce liquidity risks and ensure that the holders of stablecoins have access to their assets. Another question is whether stablecoins should be covered by government deposit insurance schemes, similar to the arrangement available to banks? See papers by the G-7 Working Group on Stablecoins (2019) and the Financial Stability Board (2020).

\subsection{Strengthen Payment Infrastructure}

The modernization of retail payment infrastructure is another area where it would be helpful to establish a "level playing field". Compared to cryptocurrencies, individuals and corporations cannot currently execute transactions in real time, which is a disadvantage compared to the peer-to-peer networks used by cryptocurrencies (Note 25). However, policymakers and private sector entities are already innovating in this area, which should be accelerated. Brainard (2021) mentions that the Federal Reserve is in the process of introducing a faster payment system (the FedNow Service), which would allow real-time, around the clock settlements for retail customers (consumers and businesses) and enable customers to send and receive payments conveniently and quickly via mobile devices with immediate access to their funds. Other central banks are working on similar systems (e.g., UK has Faster Payments Services, Canada is testing real-time retail system (RTR), and the Reserve Bank of Australia has launched New Payment Platform (NPP), which enables retail customers to make immediate, real-time payments 24/7). These steps would eliminate, or at least considerably narrow, the disadvantage regulated settlement systems have in comparison to private cryptocurrencies, without having associated settlement and credit risks. Interoperability of regulated payment systems is essential, as emphasized by several authors, to enable a range of instruments, including regulated stablecoins, to utilize official settlement systems. Private sector operators (e.g., Visa, MasterCard, and Goldman Sachs) are examining the benefits of blockchain technologies and cryptocurrencies for making payments. See also Cecchetti and Schoenholtz (2021).

\section{Cryptocurrencies: Are They Money?}

Answer to this question would have implications for the way cryptocurrencies are regulated. According to IMF (2016, page 180), money encompasses financial instruments that are (1) widely accepted mediums of exchange and (2) could be exchanged into another medium of exchange at short notice at and close to their full nominal value. At the moment, cryptocurrencies are classified as commodities (Note 26).

Statistical definitions of money change, as they should, not only over time, as new forms of "money" are created and included in the existing definitions, but also across countries. Excluding certain forms of money while including others in the definition itself does not itself have real consequences as the excluded forms of money are still be used by 
economic actors. But they could create arbitrary boundaries for monetary statistics and complicate the interpretation of these statistics (e.g., for assessment of liquidity conditions). In order to be classified as a monetary instrument, it is important to understand the "moneyness" of these instruments, that is, to what extent they provide liquidity, are broadly accepted mediums of exchange, and provide a stable store of nominal value? O'Brien (2006), for instance, shows that the composition of narrow money aggregate (usually labeled as M1) is rather similar across countries, comprising currency issued by central banks and demand (or liquid) deposits held by commercial banks and other financial institutions. Broader monetary aggregates (e.g., labeled as M2, M3, and M4, and so on, depending on the country) differ across countries due to variations in definitions used by the national authorities. Savings and time deposits are standard elements of broader money aggregates (i.e., M2), but countries have expanded the definitions to include money market funds, foreign currency deposits, central government deposits, and non-bank deposits, among others. The size of the deposit and the status of holder may influence its inclusion in the monetary aggregates (e.g., difference between money market mutual funds geared towards retail customers, which are often included in the monetary aggregate (e.g., M2) while institutional time deposits and money market funds are not), the original maturity of deposits, which reflects their liquidity (e.g., in the Euro-area short-term deposits are included, but longer-term deposits are not), the currency denomination of deposit, the type of money (inside and outside money), type of financial institution, location of depository institution, and deposit holder (government and non-government entities).

\subsection{E-money}

E-money is better integrated into our digital lives than conventional fiat currency and it adds a new dimension to the definition of monetary aggregates. The IMF (2016, p. 59) defines e-money as a payment instrument where monetary value is electronically stored (on a physical device or remotely on a server) and represents a claim against the issuer (Note 27). It is the digital equivalent of pre-paid card, which can be issued as a token or an account value and settled in centralized or decentralized fashion. Transactions in e-money are nearly costless and immediate, which make e-money instruments more attractive than payment cards or bank transfers. However, because of the lack of government backing e-money reflects the trustworthiness of issuer (banks and in some cases non-bank institutions, such as mobile carriers). Risks with e-money include credit and liquidity risk of the underlying assets, similar to other financial instruments, which could lead to financial losses to holders. Many countries permit financial and non-financial corporations to issue e-money (e.g., IMF (2016), p. 187), such as mobile money, which is classified as a deposit rather than currency (since it is issued by banks, which has relevance for how we might view cryptocurrencies). Furthermore, e-money can be part of broad money if it meets the definition of broad money.

In essence, e-money is a stablecoin that is fully backed by digital fiat currency and guarantees one-to-one conversion rate to government-backed money. It could be exchanged between individuals and businesses with ease and immediate effect using an app on cellphones. To qualify as e-money (e.g., electronic wallet, pre-paid cards, web-based electronic money (e.g., PayPal) and mobile money that may be accessed via mobile phones or other devise to make payments), these payment instruments must be used for making payments to a broad variety of other entities (i.e., they require interoperability). See, for instance, Adrian (2019), which is also relevant for the discussion on cryptocurrencies. The IMF highlights that the interoperability of e-money instruments could be a challenge if the settlement platforms are not compatible. For these reasons, cryptocurrencies, such as Bitcoin, are not classified as e-money but as nonfinancial assets by the IMF. They do not have stable valuations (to enable exchange at or near their full nominal value) and they are not widely accepted mediums of exchange for making payments and settling debts. See Berentsen and Schär (2018), BIS (2018a and b), and Sveriges Riksbank (2018) for discussion of the characters of money.

\subsection{Stablecoins}

Cryptocurrencies are clearly not "your grandfather's money". Their proliferation illustrates the speed of penetration of cryptocurrencies in the modern-day economy, currently in thousands, each of them displaying unique characteristics (e.g., blockchain technologies and algorithms). Most cryptocurrencies' valuations are highly volatile (e.g., Bitcoin and Ethereum, which are two largest cryptocurrencies by market capitalization), which arises from short-term inflexibility in the supply of "coins" (that need to be minted or mined) (Note 28). These cryptocurrencies are more comparable to commodities and other investment assets whose price volatility at least in the short run is driven by demand factors (e.g., artwork, gold and crude oil). They also could be considered as an alternative asset class (e.g., Goldman Sachs, 2021), primarily held for their attractiveness as an investment (seeking longer-term capital appreciation) rather than for the ability to generate income (cryptocurrencies do not have income streams) and for their usefulness for making payments (which remains limited, at least for the time being) (Note 29).

So-called stablecoins attempt to maintain the unit values of the coins stable against the chosen benchmark currency (e.g., the U.S. dollar). Tether and USD Coin are two largest stablecoins by market capitalization in this category. Unlike having a fixed or highly inflexible short-term supply, stablecoins create new units (or coins) and redeem outstanding units on demand against changes in their reserve assets, supposedly held in highly liquid forms (e.g., short-term 
Treasury securities, cash, and deposits in financial institutions). IMF (2021) note that there are substantial variations in the asset-backing of stablecoins, with different credit and liquidity risks. Some are even backed by other cryptocurrencies. There are also "algorithmic" stablecoins, which are not collateralized with liquid assets but instead intend to keep their unit value stable by managing the supply of coins (i.e., issuing new or redeeming outstanding coins using complex algorithms).

Lyons \& Viswanath-Natrai (2020) note that persistent fluctuations in the unit values of stablecoins are characterized by two-sided distributions where maximum deviations on both sides exceed 5 percent and the "half-life" of price departures range from one to ten days. Persistent deviations indicate that the stabilization mechanisms used by stablecoins are not fully successful (possibly reflecting liquidity shortfalls and speculation about sustainability of the one-to-one conversion rate). Catalini and Massari (2021) have reservations about the commercial viability of stablecoins (at least those that maintain full backing of liquid reserves) and suggest that deposit (stable)coins, issued by commercial banks with blockchain technology, would not have the same problems (Note 30). They point out that stablecoins could nonetheless expand the reach of financial services to underrepresented groups, and consequently be welfare improving, which is one of the arguments often mentioned in the context of CBDC.

The behavior of stablecoin prices is comparable to money market mutual funds or foreign currencies (see discussion below) whose valuations are not fixed to the benchmark currency, unlike banks' deposit liabilities, and are maintained through an active management of the underlying assets. Following the Global Financial Crisis, money market funds experienced significant outflows and were forced to sell their underlying assets at depressed values, eventually leading to financial losses and "breaking of the buck" (i.e., the one-to-one unit value against the U.S. dollar). In the current low interest rate environment money market funds, and similarly stablecoins, could find it difficult to maintain a fixed parity to the U.S. dollar and at the same time remain profitable.

\section{Cryptocurrencies and Financial Dollarization}

Experience suggests that cryptocurrencies are vulnerable to speculative attacks, as evidenced by their volatility, which shares similar features to "financial dollarization" where multiple currencies coexist and a substantial portion of banking system's liabilities is held in other currencies than the country's legal tender. Dollarization exposes financial institutions and their customers to exchange rate risk, which can lead to banking system fragility, disintermediation and challenge monetary policy implementation (Note 31). Levy-Yeyati (2004) shows that high degree of financial dollarization can lead to high inflation rates, high likelihood of banking crises and more volatile output growth. Lyons and Viswanath-Natraj (2020) note that cryptocurrencies' credibility hinges on their ability to maintain the preannounce parity to the U.S. dollar or another currency (Note 32).

Using the terminology typical for exchange rate regimes, by attempting to stabilize their unit value to a national currency, such as the U.S. dollar, stablecoins, are similar to "soft peg" exchange regimes where the value of currency is kept constant against the anchor currency through intervention. However, some degree of uncertainty remains in stablecoins' valuations and there is no guarantee that new monetary units are only created against increases in liquid reserves, which would impact the credibility of the parity and prompt speculative attacks (Note 33). A "hard peg" exchange regime, on the other hand, establishes a stronger institutional arrangement for setting the rate of exchange (in particular, by requiring a full backing of the outstanding units of currency at all times). A hard peg could take the form of the adoption of another country's currency as the national currency (e.g., the U.S. dollar may circulate as the legal tender). In this arrangement, a country would import the credibility of the said currency, its monetary policy and its nominal anchor, which would limit domestic liquidity creation and fiscal expansion. This is equivalent to imposing the one-to-one conversion rate between inside and outside money. Alternatively, a country could adopt a currency board arrangement where the authorities retain their own legal tender but establish institutional arrangements to redeem the outstanding monetary liabilities at a fixed exchange rate to the anchor currency and maintain a full backing of outstanding liabilities (holding official reserves at least equal to the total value of outstanding monetary liabilities).

This could point to the direction how regulatory authorities might want to address stablecoins' price instability. The above discussion suggests that the credibility of the one-to-one conversion rate for stablecoins could be enhanced by requiring them to maintain full backing of outstanding liabilities (or coins), either in the form of liquid assets (such as short-term Treasury securities) or as reserves at the central bank. Enoch and Gulde (1997) provide a fuller discussion on currency board arrangements.

\section{Final Thoughts}

Cryptocurrencies are the latest development in the evolution of banking and financial markets. Modern computer technology is enabling advances that were thought impossible only a short while ago. Changes have been impressive and have parallels in other sectors of the economy where online services and informal, peer-to-peer networks offer a 
range services to the public. The propagation of new ways to record and execute financial transactions represents a fundamental transformation of financial markets, which we need to adapt to and become familiar with.

Whether technological innovations would impair central banks' ability to carry out their operations effectively to steer market interest rates and to impact economic activity and inflation is unlikely. Given their limited acceptance as mediums of exchange for the time being, cryptocurrencies are unlikely to play a substantial role as payment mediums in the short term. Nonetheless, policymakers are rightfully concerned about their disruptive potential, which justifies closer oversight and regulation.

While the introduction of CBDC is thought by many as a perfect solution to the challenges posed by cryptocurrencies, it has its own uncertainties and may have unintended consequences. Authorities are rightly cautious in trying to avoid disturbing the balance between private (inside) and public (outside) money in the provision of financial services. In this paper we argue that CBDC should not be the first line of defense against the proliferation of cryptocurrencies and should not be adopted out of the fear of "missing out".

Nevertheless, authorities' concerns about their ability to guarantee public's access to government-backed currency is well warranted but addressing it would not in our view require the introduction of a new instrument (i.e., CBDC). Policymakers should instead utilize existing, well-understood institutional structures to address the policy challenges, which would help preserve the status quo in the financial markets and consequences be less prone to destabilizing the financial system.

While the public uses government-backed currency infrequently, ensuring access to it would be incredibly important as an available option (a kind of lender-of-last resort facility for the retail public). We propose a simple way to facilitate this by requiring depository institutions to maintain a minimum cash position (it is different from a traditional reserve requirement). Expanding central banks' footprint through the introduction of digital alternatives is not advised, at least for the time being. Preserving networks for government-backed currency should be considered as a public good and consequently central banks should sponsor the cost of holding cash and maintaining ATM networks by remunerating minimum cash reserve balances.

Regulating cryptocurrencies, which many countries are considering, would be very important to safeguard financial stability. Enabling existing financial institutions to compete with cryptocurrencies on a "level playing field" is equally important and the authorities in many countries are already addressing this, including through updates to payment systems to facilitate faster, real time, retail settlements.

As cryptocurrencies proliferate and become more money-like, new providers are likely to enter this space to compete with traditional providers of financial services, which could have significant implication for financial markets (for instance, network providers might begin to offer financial services). Competition in this space should be encouraged while such developments raise policy questions for central banks and regulators that are not necessarily clear-cut. This is an evolving field and potentially subject to significant changes that would shape financial markets in the period ahead. Future research is therefore likely to encompass a range of regulatory, institutional, and policy questions, such as the implications of expanding use of digital payment instruments for interest rates, monetary policy transmission and effectiveness, and for price stability.

\section{Acknowledgement}

The author likes to thank the editor and two reviewers for their comments and suggestions. All the remaining errors are author's responsibility.

\section{Notes}

Note 1. The emergency of informal markets, be they for credits or foreign exchange, are usually a response to the shortcomings in the formal markets (e.g., credit, interest rate, and foreign exchange controls), which inhibit effective redistribution of financial resources in the economy. For example, interest rate and credit controls during the 1980s led to informal credit markets in Europe, eventually forcing the liberalization of interest rates and credit allocation. The misalignment of official exchange rates and exchange controls often led to the development of informal markets for foreign exchange trading where exchange rates deviated from official parities.

Note 2. The first cryptocurrency was invented in 2008. The number of cryptocurrencies has grown into thousands during a relatively short period of time.

Note 3. Payments by check have continued to decline in the United States and elsewhere but they still represent an important settlement instrument.

Note 4. The Global Financial Crisis and Covid-19 pandemic have caused a dramatical, albeit a temporary, reversal in the longer-term trend for banks' reserve holdings. 
Note 5. Haasi et al. (2018) estimate that in 2016 some 60 percent of U.S. dollars were held abroad, representing a continuous upward trend since the 1970s when the share was 10 percent (the current share of $\$ 100$ dollar bills held abroad is even larger, owing to concentration of foreign demand for U.S. dollar banknotes of large denomination bills).

Note 6. This reflects the cost of maintaining ATM networks and holding a stock of physical banknotes in a safe location. In some countries, banks have started to limit the provision of cash, for instance, by specifying some of their branches as locations for teller services (and requiring that larger amounts need to be pre-ordered).

Note 7. One should be reminded that these changes are not necessarily unique to the financial markets. Comparable changes are taking place in other sectors of the economy, which have been similarly revolutionary: social interaction (Facebook and Twitter, Facetime, Skype and Zoom), which have changed the way we communicate, online retailing (Amazon), streaming of movies and TV shows (Netflix, Hulu and others), vacation rentals (Airbnb) and traveling (Uber and Lyft). There are other examples, which have been equally impactful.

Note 8. It is worth pointing out that cryptocurrencies are not only mediums of exchange (e.g., Bitcoin and Ethereum, Tether, and USD Coin), unlike physical monies. They are also digital platforms (blockchains) that record, validate, and execute transactions. Ethereum, for instance, is a cryptocurrency and a platform that may be used by other cryptocurrencies (e.g., USD Coin uses it) to execute transactions.

Note 9. Similar concerns have been noted in the context of the Diem (formerly, the Libra), which is believed to be a highly scalable cryptocurrency that could reach a large, global audience. See Kovanen (2019b) for a discussion about the prospects for Diem as a supranational currency. See also the Diem Association's White Paper (Diem Association (2020)).

Note 10. Ensuring interoperability between government-backed digital currency and other digital platforms is seen as critical for the success of CBDC.

Note 11. The consequences of CBDC are likely to be magnified for global reserve currencies, such as the U.S. dollar.

Note 12. The features of CBDC have been elaborated by several authors (e.g., Bech \& Garratt, 2017, and Adrian \& Mancini-Griffoli, 2019, among others).

Note 13. In the United States, for instance, the demand for U.S. dollars increased by $\$ 200$ billion in 2020, in the aftermath of the Covid-19 pandemic, which is significant compared to the average growth of $\$ 85$ billion per annum during the preceding ten-year period.

Note 14. For the sake of illustration, commercial banks' reserve balances at the Federal Reserve System totaled $\$ 16.6$ billion in August 2008, compared to these banks' total assets of $\$ 11$ trillion. The situation changed fundamentally subsequent to the Global Financial Crisis in 2008 and in response to the Covid-19 pandemic in 2020 as the monetary authority in the United States responded aggressively to the economic downturns and substantially expanded the central bank's balance sheet through so-called quantitative easing programs. This led to sharp increases in the financial institutions' reserve holdings at the Federal Reserve System, which still remain at very high levels. It is worth pointing out that reduction in banks' reserve balances prior to the financial crisis could also have been in response to the changes in the Federal Reserve's monetary policy operating framework, as the operational target was changed from reserves to interest rate, which complement other contributing factors behind the declining reserve usage.

Note 15. Due to commercial banks' ability to create new liabilities (inside money), liquidity is no longer entirely under the control of the central bank. In this context, McLeay, Radia and Thomas (2014) argue that the role of banks deposits is misunderstood because in a modern financial system banks can create new deposit liabilities (inside money) through their lending activities, which means that during normal times, the central bank does not fix the amount of money in circulation, although central bank could influence money creation indirectly through the cost of money (interest rate) and directly through asset purchases.

Note 16. This is effectively what the Federal Reserve is currently doing, albeit in a situation of surplus liquidity.

Note 17. Ultimately, it is about the credibility of the nominal anchor and the services it provides. In many ways, reasons for the emergency of privately issued crypto currencies are not different for the emergency of informal credit and foreign exchange markets.

Note 18. For comparison, capital of commercial and savings banks represents about 10 percent of these financial institutions' total liabilities (as of June 2021).

Note 19. Costa and Grauwe (2001) are concerned about central bank losing its traditional instruments of monetary policy and seigniorage revenue in a cashless society, which increases the risk that the central bank becoming dependent on the Treasury for income and policy influence and could erode central bank's independence and effectiveness. 
Note 20. Unremunerated reserve requirements act as a tax on financial institutions, which could have adverse implications for intermediation, the profitability of financial institutions, and lending and deposit interest rates.

Note 21. In modern banking, the distribution of banknotes and coins is the responsibility of depository institutions rather than the central bank. In countries where demand for banknotes at normal times is low (e.g., Sweden, which does not have a reserve requirement), negative network externalities may have accelerated the process of discouraging the provision of cash as banks attempt to reduce the costs associated with the provision of currency (Bounie, François and Van Hove (2014) discuss the importance of network externalities for the use of credit and debit cards).

Note 22. Please note that the characterization in O'Brien (2007) may not reflect the current situation as there may have been changes in the reserve requirement regulations in some countries since the onset of the Global Financial Crisis and the Covid-10 pandemic. See also BIS (2019).

Note 23. The percentage would need to reflect country-specific circumstances. In the United States, for instance, currency in circulation amounts to about $\$ 2$ trillion, which is 10 percent of depository institutions' deposit liabilities. The growth of currency in circulation has averaged $\$ 85$ billion per annum since 2010 but accelerated to $\$ 200$ billion in 2020 due to the Covid-19 pandemic, which represents 10 percent of banks' deposit base.

Note 24. Even for countries that currently do not subscribe to statutory reserve requirements, a minimum cash requirement could be introduced, as described above, to assist in facilitating access to physical currency.

Note 25. The concentration of payments systems, often operated by multinational corporations, has been flagged as a policy concern for payment system stability and reliability (e.g., Sveriges Riksbank, 2020).

Note 26. The U.S. Commodity Futures Trading Commission (CFTC) has classified Bitcoin as a commodity rather than a currency (CFTC (2017)). The Internal Revenue Service (IRS) issued a notice in 2014 to the users of crypto currencies, which states that trades in crypto currencies are treated as property transactions for tax purposes (Internal Revenue Service, Notice, 2014-21).

Note 27. Credit and debit cards are not e-money because there are no monetary values stored in them.

Note 28. The entire terminology used to describe cryptocurrencies as "coins" is somewhat misleading because cryptocurrencies are nothing like physical coins in circulation. They only exist in a digital format and they can only be "minted or mined" in the very abstract sense.

Note 29. Others suggest that their values stem from the value of their networks. For instance, many decentralized finance applications are being built on Ethereum blockchain network and non-fungible tokens may be purchased using the Ethereum blockchain, among many others. Yermack (2013) concludes that the Bitcoin behaves like a speculative asset and its price is uncorrelated with widely used currencies, gold, and extremely difficult to hedge. It is volatile and lacks access to the banking system and it is not used to price credits and loans. See Bianchi (2020) and Goldman Sachs (2021).

Note 30. In fractional banking, all deposit liabilities may not be backed by liquid securities as a large portion of the liabilities are used to extend longer-term credits. To compensate for this, financial institutions are required to hold minimum level of capital and are protected by government's deposit guarantee. The central bank may also provide lender-of-last resort (LOLR) support to financial institutions that experience liquidity, but not solvency problems.

Note 31. In addition, conversion into domestic currency is not automatically guaranteed and could lead to a situation where the customer is unable to convert his/her foreign currency deposits into foreign banknotes if the financial institution does not have enough foreign exchange on its account with a correspondent bank.

Note 32. Kovanen (2019a) makes similar arguments and notes that cryptocurrencies may be thought of as being issued by virtual states that have no real activity and no residents, and where there is no regulation governing the currency or requirement for physical backing (e.g., gold). Which raises the question who would guarantee the credibility of these currencies and why would anyone accept them for payments?

Note 33. Bitcoin and Ethereum, whose prices are highly volatile, could be classified as "freely floating" exchange rate regimes where the issuers do not intervene in the market to stabilize the unit values of the coins. Because of this, the values of Bitcoin and other volatile cryptocurrencies fluctuate widely, even during short periods of time.

\section{References}

Adrian, T. (2019, May). Stablecoins, Central Bank Digital Currencies, and Cross-Border Payments: A New Look at the International Monetary System. Remarks at the IMF-Swiss National Bank Conference. Zürich, Switzerland.

Adrian, T., \& Mancini-Griffoli, T. (2019, July). The Rise of Digital Money. Fintech Notes, Note/19/01. Washington, D.C. International Monetary Fund. https://doi.org/10.5089/9781498324908.063 
Adrian, T., \& Weeks-Brown, R. (2021, July). Crypto Assets as National Currency? A Step Too Far. IMF Blog, Insights and Analysis on Economics and Finance. Washington, D.C. International Monetary Fund.

Ammous, S. (2016, August). Can Cryptocurrencies Fulfil the Functions of Money? Working Paper, 92. New York, NY. Columbia University, New York Center on Capitalism and Society. https://doi.org/10.2139/ssrn.2832769

Andolfatto, D. (2018, October). Assessing the Impact of Central Bank Digital Currency on Private Banks. Working Paper Series, 2018-026B. St. Louis, Missouri. The Federal Reserve Bank of St. Louis, Economic Research Department. https://doi.org/10.20955/wp.2018.025

Arner, D., Auer R., \& Frost, J. (2020, November). Stablecoins: Risks, Potential and Regulation. BIS Working Papers, 905. Basel, Switzerland. Bank for International Settlements, Monetary and Economic Department.

Auer, R., \& Böhme, R. (2021, June). Central Bank Digital Currency: The Quest for Minimally Invasive Technology. BIS Working Papers, 948. Basel, Switzerland. Bank for International Settlements, Monetary and Economic Department.

Bank for International Settlements. (2018a). Central Bank Digital Currencies. Basel, Switzerland. Bank for International Settlements, Committee on Payments and Market Infrastructure.

Bank for International Settlements. (2018b, June). Annual Economic Report, Chapter 5. Basel, Switzerland. Bank for International Settlements).

Bank for International Settlements. (2019, December). Monetary Policy Frameworks and Central Bank Market Operations. Basel, Switzerland. Bank for International Settlements. Retrieved from https://www.bis.com.

Bank for International Settlements. (2020, June). Central Banks and Payments in the Digital Era. Annual Economic Report, Ch. 3. Basel, Switzerland. Bank for International Settlements.

Bank of England. (2021, June). New Form of Digital Money. Discussion Paper. London, United Kingdom. Bank of England.

Barrdear, J., \& Kumhof, M. (2016, July). The Macroeconomics of Central Bank Issued Digital Currencies, Staff Working Paper, 605. London, United Kingdom. Bank of England. https://doi.org/10.2139/ssrn.2811208

Bech, M., \& Garratt, R. (2017, September). Central Bank Cryptocurrencies. BIS Quarterly Review. Basel, Switzerland. Bank for International Settlements.

Berentsen, A. (1997). Monetary Policy Implications of Digital Money. Munich Personal RePEc Archive. Munich, Germany. https://doi.org/10.5210/fm.v2i7.538

Berentsen, A., \& Schär, F. (2018, Second quarter). The Case for Central Bank Electronic Money and the Non-Case for Central Bank Cryptocurrencies. Federal Reserve Bank of St. Louis, Review, 100(2), 97-106. The Federal Reserve Bank of St. Louis. St. Louis, Missouri.

Bianchi, D. (2020, Fall). Cryptocurrencies as an Asset Class? An Empirical Assessment. Journal of Alternative Investments, 23(2), 162-179. https://doi.org/10.3905/jai.2020.1.105

Bindseil, U. (2020, January). Tiered CBDC and the Financial System. Working Paper Series, 2351. European Central Bank. Frankfurt, Germany. https://doi.org/10.2139/ssrn.3513422

Bindseil, U., Manzanares, A., \& Weller, B. (2004, September). The Role of Central Bank Capital Revisited. Working Paper Series, 392. European Central Bank. Frankfurt, Germany. https://doi.org/10.2139/ssrn.586763

Bjerg, O. (2017, June). Designing New Money: The Policy Trilemma of Central Bank Digital Currency. University of Copenhagen Business School. Copenhagen, Denmark. https://doi.org/10.2139/ssrn.2985381

Bordo, M. D., \& Levin., A. T. (2017, August). Central Bank Digital Currency and the Future of Monetary Policy. NBER Working Paper, 23711. National Bureau of Economic Research. Cambridge, Massachusetts. https://doi.org/10.3386/w23711

Bounie, D., François, A., \& Van Hove, L. (2015, September). Consumer Payment Preferences, Network Externalities, and Merchant Card Acceptance: An Empirical Investigation. (Unpublished). Paris, France. https://doi.org/10.1007/s11151-016-9543-y

Brainard, L. (2021, May 24). Private Money and Central Bank Money as Payments Go Digital: An Update on CBDCs. Remarks at the Consensus by CoinDesk 2021 Conference. Board of Governors of the Federal Reserve System. Washington, D.C.

Carstens, A. (2021, January). Digital Currencies and the Future of the Monetary System. Remarks at Hoover Institution's policy seminar. Bank for International Settlements. Basel, Switzerland. 
Catalini, C., \& Massari, J. (2021, August). Stablecoins and the Future of Money. Harvard Business Review. Harvard University. Cambridge, Massachusetts.

Cecchetti, S., \& Schoenholtz, K. (2021, July). Central Bank Digital Currency: The Battle for the Soul of the Financial System, Vox, CEPR Policy Portal. Center for Economic Policy Research. London, United Kingdom.

Chiu, J., Davoodalhosseini, M., Jiang, J., \& Zhu, Y. (2019, May). Bank Market Power and Central Bank Digital Currency: Theory and Quantitative Assessment. Staff Working Paper, 2019-20. Bank of Canada, Funds Management and Banking Department. Ottawa, Ontario, Canada. https://doi.org/10.2139/ssrn.3331135

Commodity Futures Trading Commission (2017, December 1). CFTC Statement on Self-Certification of Bitcoin Products by CME, CFE, and Cantor Exchange. Press Release. Commodity Futures Trading Commission (CFTC). Washington, D.C.

Costa, C., \& De Grauwe, P. (2001, July). Monetary Policy in a Cashless Society (Unpublished). Bank of Portugal, Lisbon, Portugal and Center for Economic Policy Research and University of Leuven, London, United Kingdom. https://doi.org/10.4324/9780203222614.pt4

Davoodalhosseini, S., Mohammad R., \& Rivadeneyra, F. (2018, April). A Policy Framework for E-Money: A Report on Bank of Canada Research. Staff Discussion Paper, 2018-5. Bank of Canada, Funds Management and Banking Department). Otttawa, Ontario, Canada.

Engert, W., \& Fung, B. S. C. (2017). Central Bank Digital Currency: Motivations and Implications. Staff Discussion Paper, 2017-16. Bank of Canada, Office of the Superintendent of Financial Institutions. Ottawa, Ontario.

Enoch, C., \& Gulde, A. M. (1997, November). Making a Currency Board Operational. IMF Working Paper. Policy Analysis and Assessment, PPAA/97/10. International Monetary Fund. Washington, D.C.

Federal Reserve Bank of St. Louis, FRED Economic Data. Retrieved from http://research.stlouisfed.org/fred2/. The Federal Reserve Bank of St. Louis. St. Louis, Missouri.

Federal Reserve System. (2019). The 2019 Federal Reserve Payments Study. The Federal Reserve System. Washington, D.C.

Federal Reserve System. (2020). 107th Annual Report of the Board of Governors of the Federal Reserve System. The Board of Governors of the Federal Reserve System. Washington, D.C.

Fernándes-Villaverde, J., \& Sanches, D. (2018, February). Can Currency Competition Work? Working Papers, 18-07. The Federal Reserve Bank of Philadelphia, Research Department. Philadelphia, Pennsylvania.

Financial Stability Board. (2020, October.) Regulation, Supervisory and Oversight of 'Global Stablecoin' Arrangements, Final Report and High-Level Recommendations. Financial Stability Board. Basel, Switzerland.

Freedman, C. (2000, October). Monetary Policy Implementation: Past, Present and Future: Will the Advent of Electronic Money Lead to the Demise of Central Banking? (Unpublished). Bank of Canada. Ottawa, Ontario. https://doi.org/10.1111/1468-2362.00049

Friedman, B. M. (2000). Decoupling at the Margin: The Threat to Monetary Policy from the Electronic Revolution in Banking. International Finance, 3(2), 261-272. https://doi.org/10.1111/1468-2362.00051

Fullenkamp, C., \& Nsouli, S. M. (2004, February). Six Puzzles in Electronic Money and Banking. IMF Working Paper, WP/04/19. International Monetary Fund). Washington, D.C. https://doi.org/10.5089/9781451843774.001

G-7 Working Group on Stablecoins. (2019, October). Investigating the Impact of Global Stablecoins. Committee on Payments and Market Infrastructures. Bank for International Settlements. Basel, Switzerland.

Goldman Sachs. (2021, May 21). Crypto: A New Asset Class? Global Macro Research, Top of Mind, 98. Goldman Sachs. New York, NY.

Goncharov, I., Ioannidou, V., \& Schmalz, M. C. (2018, December). (Why) Do Central Banks Care About Their Profits? (Unpublished). University of Lancaster, Lancaster, United Kingdom, and University of Michigan, Ann Arbor, Michigan. https://doi.org/10.2139/ssrn.3005887

Gupta, S., Lauppe, P., \& Ravishankar, S. (2017, October). Fedcoin: A Blockchain-Backed Central Bank Cryptocurrency (Unpublished). Yale University. New Haven, Connecticut.

Haasi, T., Schulhofer-Wohl, S., \& Paulson, A. (2018). Understanding the Demand for Currency at Home and Abroad. Chicago Fed Letter, No. 396. The Federal Reserve Bank of Chicago. Chicago, Illinois. https://doi.org/10.21033/cfl-2018-396

Henckel, T., Ize, A., \& Kovanen, A. (1999, July). Central Bank Without Central Bank Money. IMF Working Papers, 
WP/99/92. International Monetary Fund. Washington, D.C. https://doi.org/10.5089/9781451851571.001

International Monetary Fund. (2016). Monetary and Financial Statistics Manual and Compilation Guide. International Monetary Fund. Washington, D.C.

International Monetary Fund. (2021, October). The Crypto Ecosystem and Financial Stability Challenges. Global Financial Stability Report, Chapter 2. International Monetary Fund. Washington, D.C.

International Revenue Service (2014)., Notice, N-14-21. Retrieved from http://www.irs.gov. International Revenue Service. Washington, D.C.

Ize, A., \& Oulidi, N. (2009, January). Why Do Central Banks Go Weak? IMF Working Paper, WP/09/13. International Monetary Fund. Washington, D.C. https://doi.org/10.5089/9781451871609.001

Keister, T., \& Sanches, D. (2019, June). Should Central Banks Issue Digital Currency? Working Papers, WP 19-26. The Federal Reserve Bank of Philadelphia, Research Department. Philadelphia, Pennsylvania. https://doi.org/10.21799/frbp.wp.2019.26

King, M. (1999). Challenges for Monetary Policy: New and Old. Bank of England Quarterly Bulletin, 39, 397-415. Bank of England. London, United Kingdom.

Kovanen, A. (2019a). Competing With Bitcoin-Some Policy Considerations for Issuing Digitalized Legal Tenders. International Journal of Financial Research, 10(4), 1-16. https://doi.org/10.5430/ijfr.v10n4p1

Kovanen, A. (2019b). Will the Libra Become a Supranational Currency? Some Thoughts. (Unpublished). Alexandria, Virginia.

Kumhof, M., \& Noone, C. (2018, May). Central Bank Digital Currencies-Design Principles and Balance Sheet Implications. Staff Working Paper, 725. Bank of England. London, United Kingdom. https://doi.org/10.2139/ssrn.3180713

Levy-Yeyati, E. (2004, April). Financial Dollarization: Evaluating the Consequences. (Unpublished). Universidad Torcuato Di Tella. Buenos Aires, Argentina.

Lyons, R. K., \& Viswanath-Natraj, G. (2020, May). What Keeps Stablecoins Stable? (Unpublished). University of California and Coventry, Berkeley, California, and University of Warwick Business School, Warwick, United Kingdom. https://doi.org/10.3386/w27136

McLeay, M., Radia, A., \& Thomas, R. (2014). Money Creation in the Modern Economy. Quarterly Bulletin, Quarter 1, 14-27. Bank of England. London, United Kingdom.

Meaning, J., Dyson, B., Barker, J., \& Clayton, E. (2018, May). Broadening Narrow Money: Monetary Policy with a Central Bank Digital Currency. Staff Working Paper, 724. Bank of England. London, United Kingdom. https://doi.org/10.2139/ssrn.3180720

O'Brien, Y. C. (2006, November). Measurement of Monetary Aggregates Across Countries. 2006-02. Board of Governors of the Federal Reserve System, Division of Research and Statistics and Monetary Affairs. Washington, D.C. https://doi.org/10.17016/FEDS.2007.02

O’Brien, Y. C. (2007), July). Reserve Requirement Systems in OECD Countries. 2007-54. Board of Governors of the Federal Reserve System, Division of Research and Statistics and Monetary Affairs. Washington, D.C. https://doi.org/10.17016/FEDS.2007.54

Piazzesi, M., \& Schneider, M. (2020, March). Credit Lines, Bank Deposits or CBDC? Competition and Efficiency in Modern Payment Systems. (Unpublished). Stanford University. Stanford, California.

Stella, P. (1997, July). Do Central Banks Need Capital? IMF Working Paper, WP/97/83. International Monetary Fund. Washington, D.C. https://doi.org/10.5089/9781451850505.001

Stella, P. (2008, February). Central Bank Financial Strength, Policy Constraints, and Inflation. IMF Working Paper, WP/08/49. International Monetary Fund. Washington, D.C. https://doi.org/10.5089/9781451869118.001

Sveriges Riksbank. (2018). Special Issue on the E-Krona. Economic Review, 3. Sveriges Riksbank. Stockholm, Sweden.

Sveriges Riksbank. (2020). Second Special Issue on the E-Krona. Economic Review, 2. Sveriges Riksbank. Stockholm, Sweden.

The Diem Association (2020). White Paper, V.2, Retrieved from https://www.diem.com/en-us/white-paper. The Diem Association.

Waller, C. (2021, August). CBDC: A Solution in Search of a Problem? Remarks at the American Enterprise Institute. American Enterprise Institute. Washington, D.C. 
Woodford, M. (1997, August). Doing Without Money: Controlling Inflation in a Post-Monetary World. (Unpublished). Princeton University. Princeton, New Jersey. https://doi.org/10.3386/w6188

Woodford, M. (2000, August). Monetary Policy in a World Without Money. NBER Working Paper, 7853. National Bureau of Economic Research. Cambridge, Massachusetts. https://doi.org/10.3386/w7853

Yermack, D. (2013, December). Is Bitcoin a Real Currency? An Economic Appraisal. NBER Working Paper, 19747. National Bureau of Economic Research. Cambridge, Massachusetts. https://doi.org/10.3386/w19747

\section{Copyrights}

Copyright for this article is retained by the author(s), with first publication rights granted to the journal.

This is an open-access article distributed under the terms and conditions of the Creative Commons Attribution license which permits unrestricted use, distribution, and reproduction in any medium, provided the original work is properly cited. 